\title{
Lack of the peroxiredoxin 6 gene causes impaired spatial memory and abnormal synaptic plasticity
}

Sarayut Phasuk ${ }^{1,2}$, Sureka Jasminn³, Tanita Pairojana' ${ }^{1}$ Hsueh-Kai Chang ${ }^{4}$, Kai-Chi Liang ${ }^{1}$ and Ingrid Y. Liu ${ }^{1 *}$ (D)

\begin{abstract}
Peroxiredoxin 6 (PRDX6) is expressed dominantly in the astrocytes and exerts either neuroprotective or neurotoxic effects in the brain. Although PRDX6 can modulate several signaling cascades involving cognitive functions, its physiological role in spatial memory has not been investigated yet. This study aims to explore the function of the Prdx6 gene in spatial memory formation and synaptic plasticity. We first tested Prdx $6^{-/-}$mice on a Morris water maze task and found that their memory performance was defective, along with reduced long-term potentiation (LTP) in CA3-CA1 hippocampal synapses recorded from hippocampal sections of home-caged mice. Surprisingly, after the probe test, these knockout mice exhibited elevated hippocampal LTP, higher phosphorylated ERK1/2 level, and decreased reactive astrocyte markers. We further reduced ERK1/2 phosphorylation by administering MEK inhibitor, U0126, into $\operatorname{Prdx6}^{-1-}$ mice before the probe test, which reversed their spatial memory deficit. This study is the first one to report the role of PRDX6 in spatial memory and synaptic plasticity. Our results revealed that PRDX6 is necessary for maintaining spatial memory by modulating ERK1/2 phosphorylation and astrocyte activation.
\end{abstract}

Keywords: Peroxiredoxin 6, Spatial memory, Long-term potentiation, Neuroinflammation, Reactive astrocyte

\section{Highlights}

- The Prdx6 gene plays a critical role in spatial memory formation tested with the Morris water maze.

- Lack of Prdx6 gene causes homeostatic dysregulation of hippocampal long-term potentiation (LTP).

- The Prdx6 $6^{-1-}$ knockout mice have less reactive astrocytes in the hippocampus.

- Hyperphosphorylation of ERK1/2 in the hippocampus leads to impaired spatial memory of $\operatorname{Prdx} 6^{-/-}$ mice.
*Correspondence: ycliu@gms.tcu.edu.tw

1 Institute of Medical Sciences, Tzu Chi University, Hualien, Taiwan

Full list of author information is available at the end of the article

\section{Introduction}

Spatial memory impairment is one of the most common pathologies in aging processes, early Alzheimer's disease, and some psychiatric disorders [1-3]. Oxidative damage and inflammation are two major causes of spatial memory impairment in these brain diseases [4]. The level of reactive oxygen species (ROS) is regulated by antioxidants during synaptic plasticity [5]. Either lower or higher levels of ROS than homeostatic level may cause impairment of synaptic plasticity and memory performance. Although growing evidence has revealed that various endogenous antioxidant enzymes regulate oxidative defense mechanisms and inflammatory responses [6,7], their physiological roles in modulating cellular signaling for synaptic plasticity and spatial memory formation are not clear yet.

Peroxiredoxins (PRDXs) belong to a conserved 6-member superfamily of peroxidases that exist in many organisms [8]. Among the six members (PRDX 1-6), peroxiredoxin 6 (PRDX6) contains only 1-cysteine (1-cys) original author(s) and the source, provide a link to the Creative Commons licence, and indicate if changes were made. The images or other third party material in this article are included in the article's Creative Commons licence, unless indicated otherwise in a credit line to the material. If material is not included in the article's Creative Commons licence and your intended use is not permitted by statutory regulation or exceeds the permitted use, you will need to obtain permission directly from the copyright holder. To view a copy of this licence, visit http://creativecommons.org/licenses/by/4.0/. The Creative Commons Public Domain Dedication waiver (http://creativeco mmons.org/publicdomain/zero/1.0/) applies to the data made available in this article, unless otherwise stated in a credit line to the data. 
residue and is the only one that performs multiple functions, including peroxidase and acidic calcium-independent phospholipase A2 (aiPLA2) activities [8]. And it is expressed throughout the body, with a high expression level in the brain $[9,10]$. The PRDX6 participates in oxidative defense mechanisms, phospholipid metabolism, lipid peroxidation repair, and inflammatory signaling [11-13]. It is also related to neurodegenerative diseases, including Parkinson's disease, Alzheimer's disease, and some diseases caused by chronic inflammatory response [14-16]. Gert Lubec et al. recently reported the relationship between antioxidant activity of PRDX6 and spatial memory performance [17]. Another study also revealed its role in inhibiting neurogenesis [10]. Since PRDX6 can either reduce or elevate ROS level, depending on the conditions [18-20], we hypothesized that PRDX6's function might affect synaptic plasticity and spatial memory performance.

In the central nervous system (CNS), PRDX6 is dominantly expressed in the astrocytes, and not much in the neurons $[21,22]$. The activation of astrocytes is required for maintaining sufficient energy supply to the neurons, the homeostasis of neurotransmitters, and the release of inflammatory cytokines such as tumor necrosis factor-alpha (TNF $\alpha)$ [23], interleukin 1 beta (IL-1 $\beta)$, and interleukin 6 (IL-6) [24]. Astrocytes are also crucial for modulating synaptic plasticity and memory performance $[25,26]$. Molecular studies have revealed that PRDX6 can mediate several signaling molecules involving in memory processes, including ERK1/2 [27], protein kinase B (Akt) [28], p38 MAPK [27], as well as inflammatory cytokines like TNF $\alpha$ [15], IL-1 $\beta$ [15], IL-6 [29], and CC chemokine ligand 5 (CCL5) [30].

To identify the function of PRDX6 in spatial memory, we subjected $\operatorname{Prdx6}$ knockout $\left(\operatorname{Prdx6^{-/-}}\right)$ mice to the MWM test, evaluated their motor coordination with the rotarod test, and measured their anxiety behavior with the light/dark transfer tests. Following the behavioral tests, we recorded hippocampal synaptic plasticity using the extracellular recording technique and measured expression levels of several related molecules in the hippocampus using western blot analysis.

\section{Materials and methods}

\section{Animals}

Dr. Shun-Ping Huang at Tzu Chi University, Taiwan provided Prdx6 wild-type $\left(\operatorname{Prdx6^{+/+}}\right)$ and knockout $\left(\operatorname{Prdx} 6^{-/-}\right)$mice $(12-14$ weeks of age). The lack of the $\operatorname{Prdx} 6$ expression was generated by replacing exons 1 and 2 with neomycin drug resistance and Bgal genes. The details for creating $\operatorname{Prdx6^{-/-}}$ mice were explained in the previous study [31]. Mutant mice were backcrossed with C57BL/6J mice for more than 9 generations. All mice were produced in our laboratory by mating a heterozygous knockout $\left(\operatorname{Prd} x 6^{+/-}\right)$male with two $\operatorname{Pr} d x 6^{+/-}$ female mice or intercrossed with the same genotypes. The genotypes were confirmed by polymerase chain reaction (PCR) using specific primers (Additional file 2: Table. S1) [31]. Mice were maintained in the Laboratory animal center of Tzu Chi University with ad libitum access to food and water under a constant $12 \mathrm{~h}$ light/dark cycle. All procedures were reviewed and approved by the Institutional Animal Care and Use Committee of Tzu Chi University, Taiwan (approval \#104099), and is in accordance with the Taiwan Ministry of Science and Technology guidelines for the ethical treatment of animals.

\section{Intraperitoneal injection (i.p.) of MEK inhibitor (U0126)}

The MEK inhibitor U0126 was purchased from Promega (\#V112A, Promega Co., USA). The inhibitor was then dissolved in $234 \mu \mathrm{l}$ of DMSO to obtain stock concentration $(10 \mathrm{mM})$. The inhibitor was then diluted in $0.9 \%$ normal saline to get the final concentration $50 \mu \mathrm{M}$ for further experiment. We used normal saline containing $0.5 \%$ DMSO as the sham control solution (vehicle). In the present study, we used intraperitoneal injection to deliver the inhibitor U0126 [32]. Mice were intraperitoneally injected with $100 \mu \mathrm{l}$ of $0.9 \%$ normal saline every day from the first day of the visible platform trial until the last day of training to exclude the effect of handling and injection. One hour before the probe test, mice received $100 \mu \mathrm{l}$ of either vehicle or U0126 via i.p. injection. The protein samples were then collected from the hippocampi immediately after the completion of the probe test.

\section{Behavioral experiments Morris water maze test}

The procedure for Morris water maze test was adapted from the previous study [33]. A circular pool (diameter $110 \mathrm{~cm}$, height of the platform $-21 \mathrm{~cm}$ ) was filled with water at room temperature $\left(21^{\circ} \mathrm{C} \pm 1{ }^{\circ} \mathrm{C}\right)$. The water was made opaque with a non-toxic white paint (Cat. \# 187203, Palmer paint products, USA). Four points equally dividing the pool into four quadrants, and a round platform (10 cm in diameter) was placed in one of the quadrants. The visible platform test was carried out on the first day (6 trials per day). We placed the platform $0.5 \mathrm{~cm}$ above the water surface and trained the mice to find the visible platform within $60 \mathrm{~s}$. The starting point for each trial was randomly selected among the four quadrants (Additional file 2: Table. S2). In the hidden platform test, the platform was kept $1 \mathrm{~cm}$ beneath the water surface in the northeast (NE) quadrant. Mice were randomly placed into the water maze but not in the southwest quadrant (SW) (Additional file 2: Table. S3). They were given six trials per day, each for $60 \mathrm{~s}$, to find the hidden platform for five 


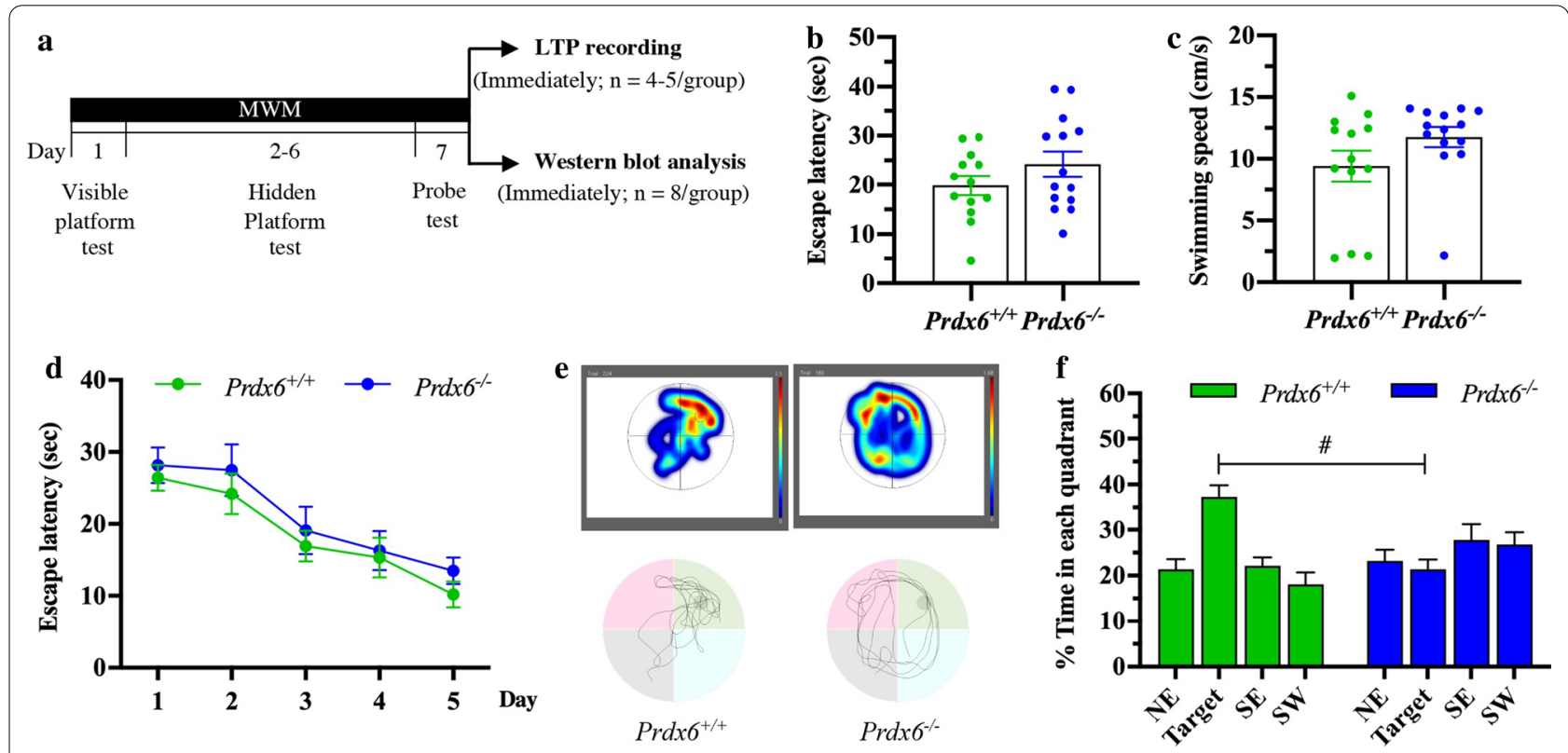

Fig. $1 \mathrm{Prdx6}^{-/-}$mice displayed impaired performance of spatial reference memory in the Morris water maze (MWM) task. a Timeline of MWM task and sample collection. b Escape latency to platform, and $\mathbf{c}$ mean swimming velocity during visible platform trial ( $\mathrm{n}=13-14$ mice/group). d Learning curve during 5 days of training. e Representation of the time spent throughout the water maze using a heat map (upper panel) and illustration of the swimming pattern (lower panel) during the probe test. $\mathbf{f}$ Percent time spent in each quadrant during probe test. All data are presented as mean \pm SEM. ${ }^{\#} p<0.05$, mixed-design repeated measure ANOVA followed by Bonferroni's post hoc test with unpaired Student's $t$ test for individual differences between groups within each quadrant

consecutive days. If they did not reach the platform, they were guided to the platform and left there for $10 \mathrm{~s}$ for the mice to locate the platform with visual cues. On day 7 , a probe test was performed with the platform removed from the pool. Each mouse was placed at an unfamiliar starting point (southwest, SW) and allowed to swim freely for $60 \mathrm{~s}$. We used a video camera and tracking system (EthoVision XT 15, Noldus Information Technology) to measure the escape latency, swimming speed, and percentage of time spent in each quadrant. After completing a probe test, we collected 8 protein samples from 8 mice and used the remaining mice for LTP recording (Fig. 1a). The corresponding behavioral data was shown in Fig. 1. In this study, the same animals were used for Figs. 1, 4, 5, and 7 .

\section{Open field test}

To investigate their motor function and anxiety response, another batch of animals was used for Fig. 2. The open field chamber was placed under the dim light condition with a top-down video recorder. Mice were allowed to explore the nontransparent chamber for $10 \mathrm{~min}$ freely. The distance traveling and moving speed were analyzed by video tracking software (EthoVision XT 15, Noldus Information Technology) and were calculated to measure locomotor activity. For anxiety-like behavior, the chamber was divided into three areas (outer, middle, and inner) to obtain the time spent in each area along $10 \mathrm{~min}$ of exploration.

\section{Rotarod test}

For the rotarod test, mice were left on the rotating rod for $60 \mathrm{~s}$ per trial with constant speed on the training day. To evaluate the motor coordination, trained mice were set on the rod with a gradual increase in speed from 4 to $40 \mathrm{rpm}$ within $300 \mathrm{~s}$ per trial. The latency to fall and maximum speed was calculated.

\section{Light-dark transfer test}

The light-dark apparatus is divided into two compartments, dark $(25 \times 25 \times 35 \mathrm{~cm})$ and light $(25 \times 25 \times 35 \mathrm{~cm}$, $700 \mathrm{~lx}$ ) connected with the sliding door located on the floor at the center of the partition. The mice were placed in a light division and allowed to explore the apparatus for $5 \mathrm{~min}$ freely. The distance traveled and moving speed were recorded using a camera, and scored using automated software (EthoVision XT 15, Noldus Information Technology). To investigate the anxiety-like behavior, total time spent in the light compartment and number of entries to the light compartment were recorded. Time 


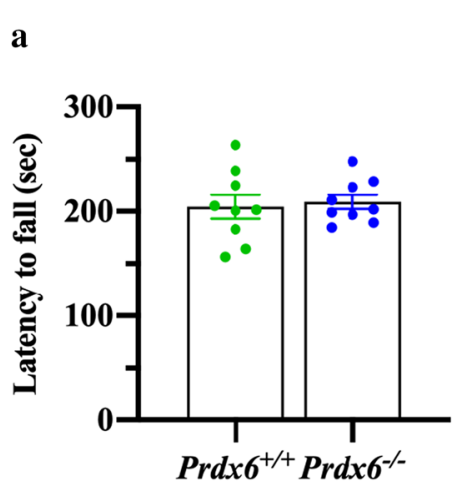

b
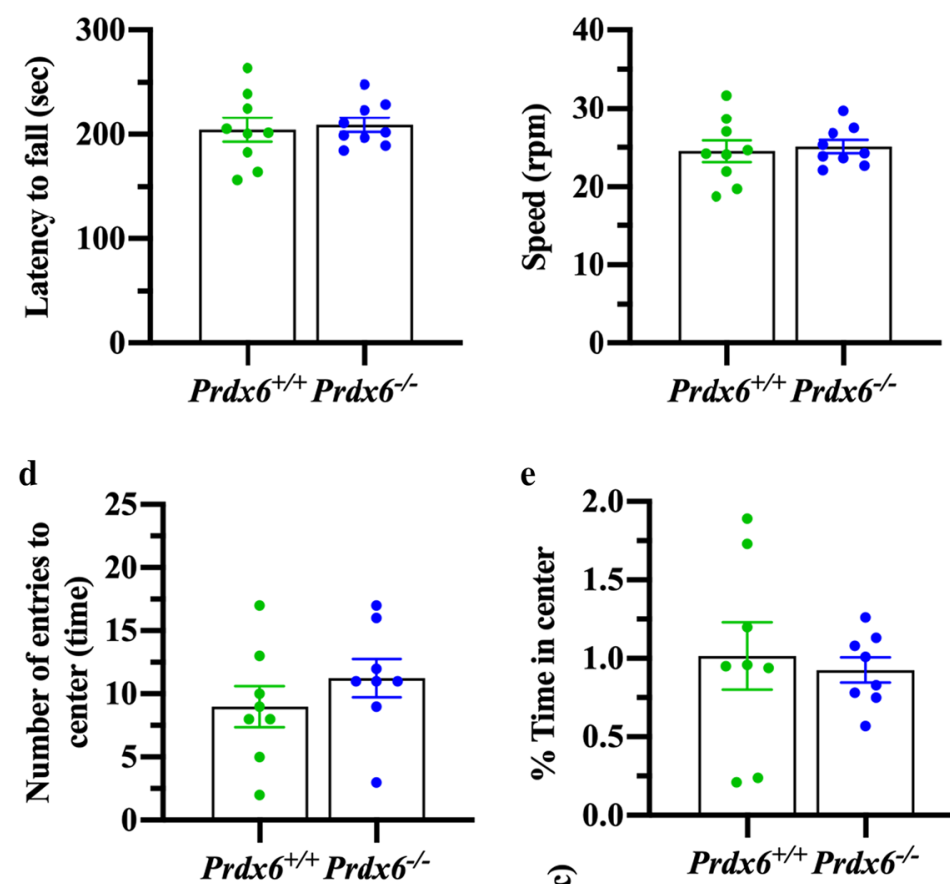

g

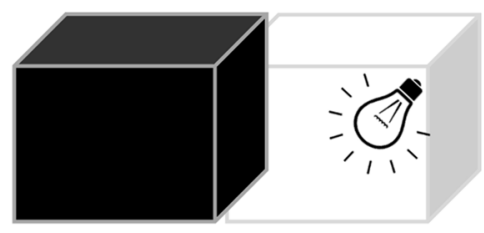

$10 \min$

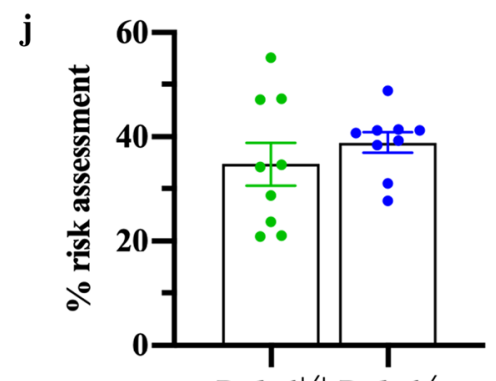

$\operatorname{Prdx6^{+/+}} \operatorname{Prdx}^{-/-}$ e

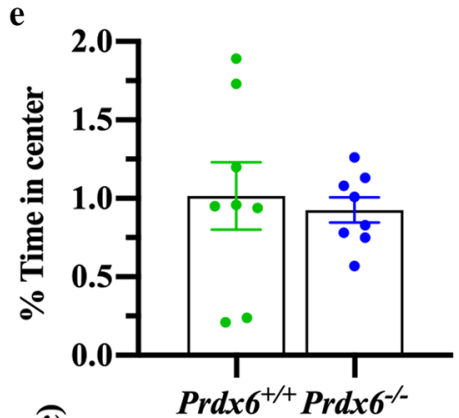

h

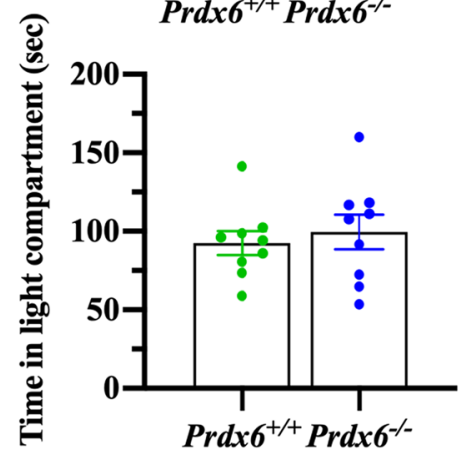

k

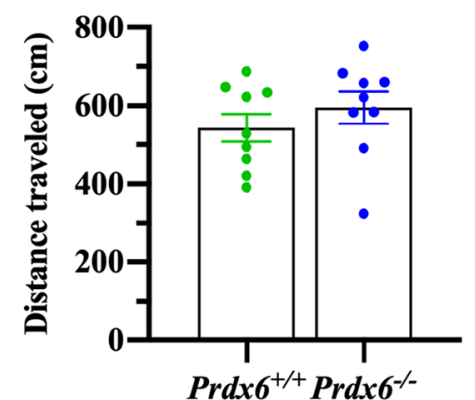

c
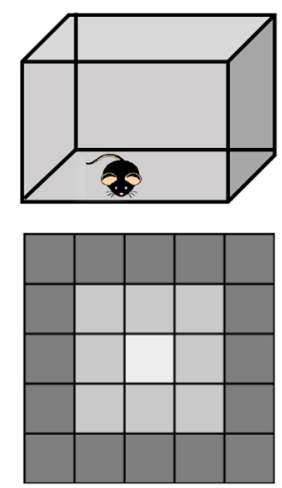

$10 \mathrm{~min}$

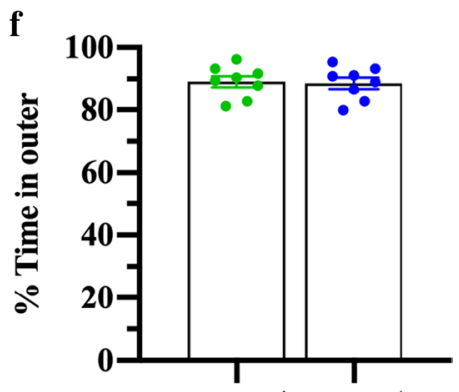

$\operatorname{Prdx6}^{+/+} \operatorname{Prdx6}^{6--}$

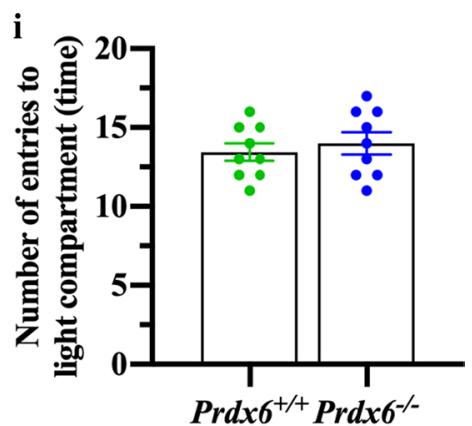

l

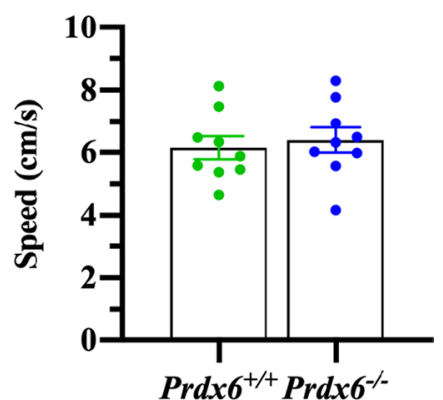

Fig. 2 Normal locomotor functions and anxiety-like behaviors in $\operatorname{Prd} d \sigma^{-1-}$ mice. a Time remained on an acceleration rota rod (sec) before falling ( $n=9$ mice/group) and $\mathbf{b}$ mean rotational velocity (rpm) at the time of falling. $\mathbf{c}$ Schematic of zones in the open field arena. $\mathbf{d}$ Number of entries into the center of an open field arena ( $n=8$ mice/group). e and $\mathbf{f}$ Percent time spent in the center (e) and outer (f) areas in the open field arena. $\mathbf{g}$ Schematic of light/dark transfer test. $\mathbf{h}$ Time spent in the light compartment ( $n=9$ mice /group). i Number of entries into the light compartment. $\mathbf{j}$ Percent risk assessment during 10 min of exploration. $\mathbf{k}$ Distance traveled, and I moving speed in the light compartment during light/dark transfer test. All data are presented as mean \pm SEM., unpaired Student's $t$ test following a normal distribution 
spent in the risk arena $(3 \mathrm{~cm}$ length-wise $\times 6 \mathrm{~cm}$ widthwise surrounding the sliding door) and in the outside risk assessment zone was also calculated as the percentage of risk assessment time.

\section{Extracellular LTP recording}

We adapted the procedure reported in a previous study with a slight modification to record long-term potentiation [34]. Both $\operatorname{Prdx} 6^{+/+}$and $\operatorname{Prdx} 6^{-/-}$mice were anesthetized with isoflurane and sacrificed by guillotine at naive (basal) condition, and after the completion of the probe test. Whole brains were immediately removed and washed in ice-cold artificial cerebrospinal fluid (ACSF). The brains were then sticked on the metal chamber of a vibrating microtome (Leica VT1000 S, Leica Biosystems Inc., Nussloch, Germany). The brains were horizontally sectioned in oxygenated $\left(95 \% \mathrm{O}_{2}\right.$ and $\left.5 \% \mathrm{CO}_{2}\right)$ ACSF at $350 \mu \mathrm{m}$ thickness. The brain slices were transferred into the tissue chamber containing oxygenated ACSF in the incubated boxes and recovered at temperature $28-30{ }^{\circ} \mathrm{C}$ for at least $2 \mathrm{~h}$. The brain slices were transferred to a recording chamber for extracellular LTP recording. During recording, hippocampal slices were perfused with oxygen $\left(\mathrm{O}_{2}\right)$ saturated ACSF at a speed of $2-3 \mathrm{~mL} / \mathrm{min}$ with $28{ }^{\circ} \mathrm{C}$. The glass pipettes were pulled on a micropipette puller (PC-10 Needle Puller, Narishige, Japan) filled with normal ACSF. This recording electrode was placed at the stratum radiatum of the CA1 region for recording the excitatory postsynaptic field potentials (fEPSPs). The unipolar stainless-steel microelectrodes (Frederick Haer Company, Bowdoinham, ME, USA) were used as a stimulus electrode. The stimulation intensity was adjusted between 4 and $15 \mathrm{~V}$ for each slice, so that the fEPSP were elicited to approximately $35-40 \%$ of the maximal response. Baseline fEPSP were evoked every $20 \mathrm{~s}$ for 10 and $20 \mathrm{~min}$ followed by high-frequency stimulation (HFS), which includes 3 trains of 100 pulses at $100 \mathrm{~Hz}$ for $60 \mathrm{~s}$. Then, fEPSPs were stimulated every $20 \mathrm{~s}$ for an additional $60 \mathrm{~min}$ or $3 \mathrm{~h}$. Recordings were amplified using an Axon Multiclamp 700B amplifier (Axon Instruments, Foster City, CA). All signals were filtered at $1 \mathrm{kHz}$ and digitized at $10 \mathrm{kHz}$ by Axon Digidata 1550B plus HumSilencer (Axon Instruments, Foster City, CA) using Signal software. The downward slope of fEPSPs was recorded and analyzed by Axon pCLAMP 11 software.

\section{Western blot analysis}

After the completion of the probe trial, mice were immediately anesthetized and decapitated to extract proteins from the brain. The whole hippocampi were isolated and collected in ice-cold RIPA lysis buffer $1 \times$ (Millipore, USA) containing protease and phosphatase inhibitor. The homogenized tissues were kept on ice for another $30 \mathrm{~min}$ before centrifuging at $13,000 \mathrm{rpm}$ for $15 \mathrm{~min}$ at $4{ }^{\circ} \mathrm{C}$. The supernatants were transferred to new Eppendorf tubes and stored at $-80^{\circ} \mathrm{C}$ for further experiments. The protein samples (30-50 $\mu \mathrm{g}$ of protein) were loaded and run on $10 \%$ SDS-PAGE at $80 \mathrm{~V}$ in stacking gel and $140 \mathrm{~V}$ in resolving gel. The separated proteins were transferred to a PVDF membrane $(0.4 \mu \mathrm{m}$ pore size $)$ at $30 \mathrm{~V}$ in a cool room overnight. The blots were incubated with antiBDNF (1:2000; Abcam, UK), anti-PSD95 (1:2000; ThermoFisher, USA), anti-pERK1/2 (1:2000; Cell Signaling, Danvers, MA), anti-pAkt1 (1:1000; Cell signaling Technology, USA), anti-pCaMKII (1:2000; Abcam, UK), antiGFAP (1:2000; Abcam, UK), anti-TNF- $\alpha$ (1:1000; Abcam, UK), anti-IL6 (1:2000; Proteintech, USA) or anti- $\beta$-actin antibody (1:10,000; Sigma-aldrich) in TBST containing $0.1 \%$ BSA (ThermoFisher, USA) overnight at $4{ }^{\circ} \mathrm{C}$ room on a shaker. The blots were then incubated with either horseradish peroxidase-conjugated secondary antibody goat anti-mouse IgG (Cell signaling, Danvers, MA) or goat anti-rabbit (Santa Cruz Biotechnology, Santa Cruz, CA, USA) diluted $1: 5000$ or $1: 10,000$ in $0.1 \%$ BSA in TBST for $1 \mathrm{~h}$ at room temperature. The detail information for the antibodies used in this study is provided in Additional file 2: Table S4. The blots were washed $10 \mathrm{~min}$ for three times with TBST before imaging. For visualization, the blots were developed using ECL (Western lighting ${ }^{\circledR}$ Plus ECL, PerkinElmer Inc, MA, USA) and detected under (Bio Rad ChemiDoc MP High performance Cold light Fluorescence Analysis system). The band intensities were quantified using ImageJ 1.52a (National Institutes of Health, USA).

\section{Statistics}

The sample sizes of the animals for each experiment were provided in an Additional File 2: Table S5. Statistical analysis was performed using SPSS (version 25, IBM Corporation), and the graphs were plotted using GraphPad Prism version 8. After assessing the normality using the Shapiro-Wilk test, Student's $t$-tests were conducted compared to two independent groups with a normal distribution. In contrast, data without normal distribution was examined with Mann-Whitney U-test. For learning ability of hidden platform trials and time spent in each quadrant during probe test, the results were analyzed as mixed-design repeated-measures ANOVA with trials as within-subjects factor and genotypes as a betweensubjects factor. We used a Bonferroni-corrected $t$-test (adjusted $p \leq 0.025$ for 2 statistical tests and $p \leq 0.017$ for 3 statistical tests) to examine statistical differences between two independent groups.

For the MEK inhibitor experiment, escape latency and swimming speed were analyzed by two-way measure ANOVA with genotype and intervention as independent 
factors followed by Bonferroni's post hoc test. All data are presented as mean \pm SEM, with statistical significance at $p<0.05$. Sample sizes are described in figure legends.

\section{Results}

Prdx6 ${ }^{-1-}$ mice exhibited impaired spatial memory

To examine hippocampal-dependent spatial memory in $\operatorname{Prdx} 6^{-/-}$mice, we first conducted the Morris water maze (MWM) test (Fig. 1a). To ensure that the mice have no problem with their visual ability and locomotor function, we performed a visible platform trial on day 1 of the test. In a visible platform trial, the statistical analysis using unpaired Student's $t$-test demonstrated that there was no significant difference in the time to reach the visible platform $\left(t_{25}=-1.330\right.$, $p=0.196$, Fig. 1b) and in the mean speed of swimming $\left(t_{25}=-1.594, p=0.123\right.$, Fig. 1c) between the two genotypes. It suggested that $\operatorname{Prdx} 6^{-1-}$ mice have normal visual and sensorimotor function.

The hidden platform was fixed in the northeast (NE) quadrant in acquisition trials as a target quadrant. And the mice were then randomly placed at different starting points. Using mixed-design ANOVA, there was no effect of genotype on escape latency to find a hidden platform $\left(F_{(1,25)}=0.674, p=0.420\right.$, Fig. $\left.1 \mathrm{~d}\right)$. Both groups spent equal time locating the hidden platform across the five days of training. There was no significant effect of the interaction between the genotype and training day on escape latency $\left(F_{(4,100)}=0.136\right.$, $p=0.969$, Fig. 1d). Mice of both genotypes exhibited a normal ability to find the hidden platform indicating in decreased escape latency from training day 1 to 5 , as shown by the main effect of the training day $\left(F_{(4,100)}=23.487, p=0.000\right.$, Fig. 1d $)$. Further unpaired Student's $t$-testing revealed no difference between the two genotypes $(p>0.05$, Fig. 1d). These results suggested that deficiency of PRDX6 does not affect the acquisition of spatial memory.

To confirm that the mice used their spatial memory to find the hidden platform, mice were allowed to swim in the maze for a total of $60 \mathrm{~s}$ without the platform during the probe trial. The heat map (upper panel) and swimming patterns (lower panel) during the probe test are illustrated in Fig. 1e. We found that $\operatorname{Prdx} 6^{+/+}$mice displayed statistical differences in percent time spent in the four quadrants $\left(F_{(3,36)}=10.309\right.$, $p=0.000$, Fig. 1f), with the longest time in the target quadrant (NE) (All Bonferroni's post hoc tests were significant, $p<0.05)$. On the other hand, $\operatorname{Prdx} 6^{-/-}$mice spent equal time in all quadrants $\left(F_{(1.954,25.406)}=0.894\right.$, $p=0.0419$, Fig. 1f). Using Bonferroni-corrected $t$-test analysis, we observed that $\operatorname{Pr} d x 6^{-1-}$ mice spent significantly less time in the target quadrant than $\operatorname{Prd} x 6^{+/+}$ mice $\left(t_{25}=4.814, p=0.000\right.$, Fig. $\left.1 \mathrm{f}\right)$. These data proved that $\operatorname{Prdx6^{-/-}}$ mice exhibited spatial memory impairment in the MWM test.

\section{Spatial memory deficit in $\mathrm{Prdx6}^{-1-}$ mice was not due to locomotor activity, motor coordination, and anxiety level}

We next evaluated the motor function and anxiety response of these knockout mice. Results showed increase in distance traveled $\left(t_{-2.749}=14.000, p=0.016\right.$, Additional file 1: Fig. S1b) and moving speed ( $t$. $2.741=14.000, p=0.016$, Additional file 1: Fig. S1b) of $P r d x 6^{-1-}$ mice. These results indicated that the locomotor function of $\operatorname{Prdx} 6^{-/-}$mice is comparable to that of their wild-type littermates. To verify the influence of motor coordination in spatial memory impairment, a rotarod test was performed on another batch of animals to avoid any confounding factor. There was no difference between the two genotypes on latency to fall $\left(t_{16}=-0.356, p=0.726\right.$, Fig. $\left.2 \mathrm{a}\right)$ and speed $\left(t_{16}=-0.356\right.$, $p=0.726$, Fig. 2b). These results indicated that $\operatorname{Prdx} 6^{-/-}$ mice's spatial memory deficit is not affected by locomotor dysfunction.

The ability to navigate using spatial cues or swim in a water maze can interfere with anxiety levels [35]. To verify the influence of anxiety level on spatial memory impairment of $\operatorname{Prdx6^{-1-}}$ mice, we subjected the mice to an open field (Fig. 2c) and light/dark transfer test (Fig. 2g). After assessing the normality by using the Shapiro-Wilk test, we observed no significant difference in the number of entries to center $\left(t_{14}=-1.011, p=0.329\right.$, Fig. 2d), percentage time spent in center $\left(t_{14}=0.387\right.$, $p=0.705$, Fig. 2e), and percentage time spent in the outer zone $\left(t_{14}=0.203, p=0.842\right.$, Fig. $\left.2 \mathrm{f}\right)$ between the two genotypes. In the light/dark transfer test, no significant difference was recorded in time spent in $\left(t_{16}=-0.538\right.$, $p=0.598$, Fig. $2 \mathrm{~h})$ and number of entries into $\left(t_{16}=-\right.$ $0.618, p=0.545$, Fig. 2i) the light compartment between the two genotypes. When the risk area was drawn in the light compartment, $\mathrm{Prdx} 6^{-/-}$mice have the same percentage of risk assessment compared to their wild-type mice $(t=-0.894, p=0.385$, Fig. $2 \mathrm{j})$. We also observed equal distance traveled $\left(t_{16}=-0.945, p=0.359\right.$, Fig. $2 \mathrm{k}$ ) and moving speed $\left(t_{16}=-0.450, p=0.659\right.$, Fig. 2l) of $\operatorname{Prd} x 6^{-/-}$mice when compared to $P r d x 6^{+/+}$mice. The results obtained from the open field and light/dark transition tests confirmed that spatial memory impairment of $\operatorname{Prd} x 6^{-1-}$ mice was not affected by their anxiety-like behavior. 
Electrophysiological recording of hippocampal slices sectioned from home-caged $\mathrm{Prdx}^{-/-}$mice showed reduced hippocampal long-term potentiation (LTP) $3 \mathrm{~h}$ after HFS

To understand the cellular mechanism underlying the impairment of spatial memory in $\operatorname{Prdx6^{-/}}$ mice, we then conducted LTP recording in the CA1 region of acute hippocampal slices taken from home-caged mice (Fig. 3a). No difference in overall input-output curves ( $F$ $(1,14)=1.455, p=0.248$, Fig. $3 \mathrm{~b})$ between the two genotypes was recorded. Time course of LTP recorded from the CA1 region of $\operatorname{Prdx} 6^{-/-}$and $\operatorname{Prdx} 6^{+/+}$mice and the average of 3 traces recorded during baseline, 1st hour, and 3rd hour of LTP were shown in Fig. 3c and d,

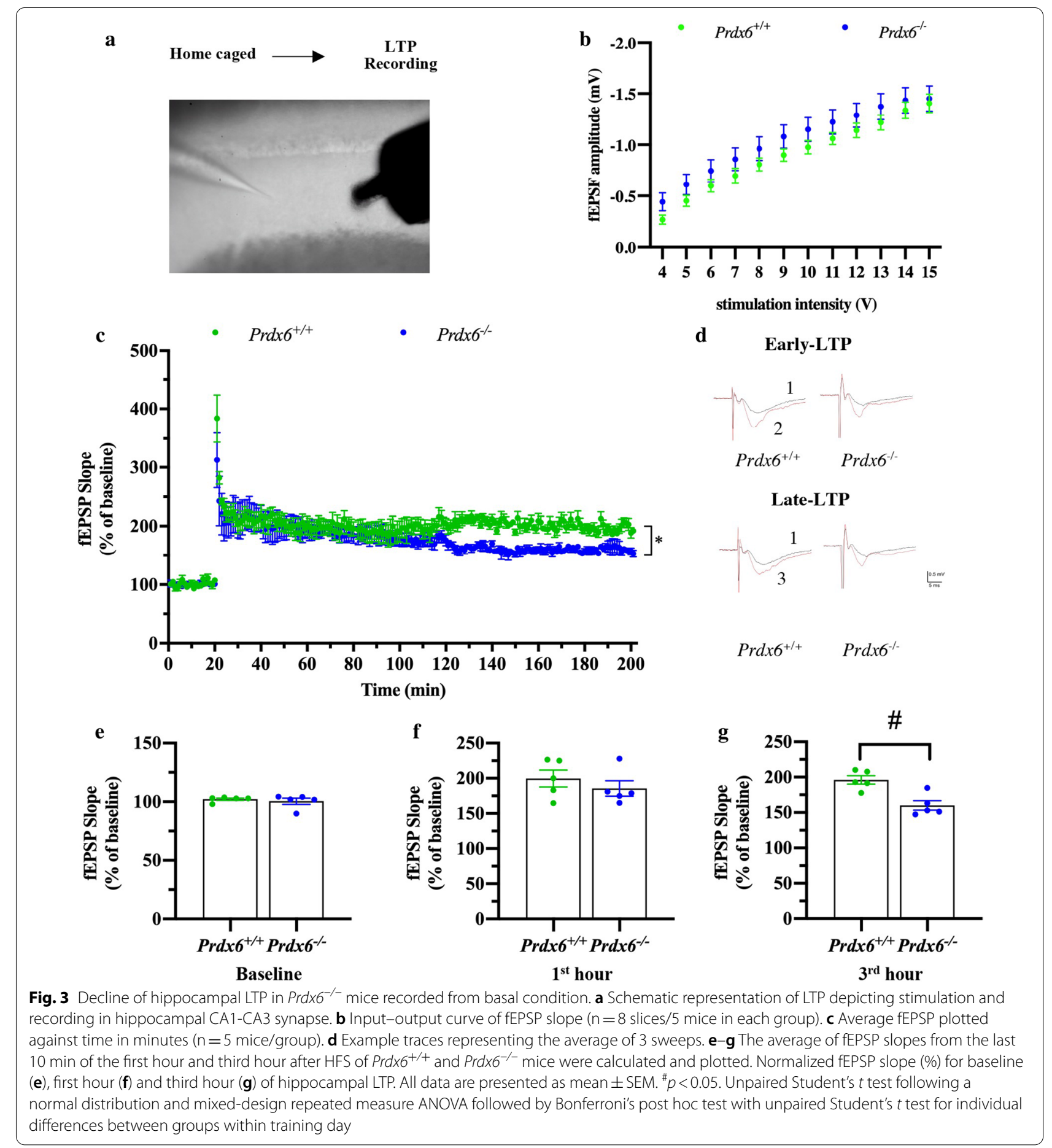


respectively. Non-parametric test indicated no statistical difference of the average percentage of baseline fEPSP slope evoked in Schaffer collateral stimulation between the two genotypes $(U=12, p=0.917$, Fig. 3c, e). The enhancement of LTP slope averaged throughout $3 \mathrm{~h}$ after high-frequency stimulation (HFS) was observed in both $\operatorname{Prd} x 6^{+/+}$and $\operatorname{Prd} x 6^{-/-}$mice $\left(F_{(1,8)}=221.436, p=0.000\right.$, Fig. 3c). Slope of LTP was similar (last $10 \mathrm{~min}$ of first hour after HFS) $\left(t_{8}=0.879, p=0.405\right.$, Fig. 3f $)$ between the two genotypes. LTP slope started from $2 \mathrm{~h}$ after HFS was significantly decreased and maintained at a lower level during $120-180 \min \left(t_{8}=4.005, p=0.004\right.$, Fig. $\left.3 \mathrm{~g}\right)$ in hippocampal slices prepared from $\operatorname{Prdx} 6^{-/-}$mice. These results indicated that lack of the $\operatorname{Prdx} 6$ causes the LTP reduction in the hippocampal CA1 region.

\section{Enhanced CA3-CA1 hippocampal long-term potentiation} (LTP) was recorded in $\mathrm{Prdx}^{-/-}$mice after the probe test

To understand whether the lack of the Prdx6 gene affects hippocampal plasticity during memory retrieval, the same set of animals described in Fig. 1a were subjected to the MWM test. After the completion of the probe test, the brains were immediately removed and sectioned for extracellular recording (Fig. 4a). Field recording of fEPSPs in CA1 of the hippocampus showed no significant difference between $\operatorname{Prdx} 6^{-/-}$and $\operatorname{Prdx} 6^{+/+}$mice in input-output curves $\left(F_{(1,12)}=0.993, p=0.339\right.$, Fig. 4b). In this experiment, we recorded LTP for $60 \mathrm{~min}$ (Fig. 4c). The baseline fEPSPs evoked in Schaffer collateral stimulation are similar in both groups $\left(t_{7}=-0.653, p=0.535\right.$, Fig. 4c, d). The slope of fEPSPs along $1 \mathrm{~h}$ of recording indicated that high-frequency stimulation (HFS; $100 \mathrm{~Hz}$ for $1 \mathrm{~s}, 3$ trains) induced the induction of hippocampal long-term potentiation (LTP) in both $\operatorname{Prdx} 6^{-/-}$and $\operatorname{Prdx6^{+/+}}$ mice $\left(F_{(1,7)}=175.403, p=0.000\right.$, Fig. $\left.4 c\right)$. Interestingly, we observed enhanced fEPSP slope calculated at the last $10 \mathrm{~min}\left(t_{7}=-4.447, p=0.003\right.$, Fig. $\left.4 \mathrm{e}\right)$ in $\operatorname{Prdx} 6^{-/-}$mice compared to $\operatorname{Pr} d x 6^{+/+}$mice.

\section{Hyperphosphorylation of ERK $1 / 2$ and upregulation of PSD95 and CPLA2 were detected in the hippocampus after a probe test in $\mathrm{Prdx6^{-I- }}$ mice}

To better understand the molecular mechanism underlying spatial memory deficit, we investigated expression of various synaptic proteins after the probe test (Fig. 5a), including BDNF, PSD95, phosphorylated ERK1/2, cPLA2, phosphorylated Akt1, and phosphorylated CaMKII. Western blot analysis revealed no significant difference in pro BDNF $\left(t_{14}=0.378, p=0.711\right.$, Additional file 1: Fig. S2a, b) and mature $\operatorname{BDNF}\left(t_{12}=-1.021\right.$,

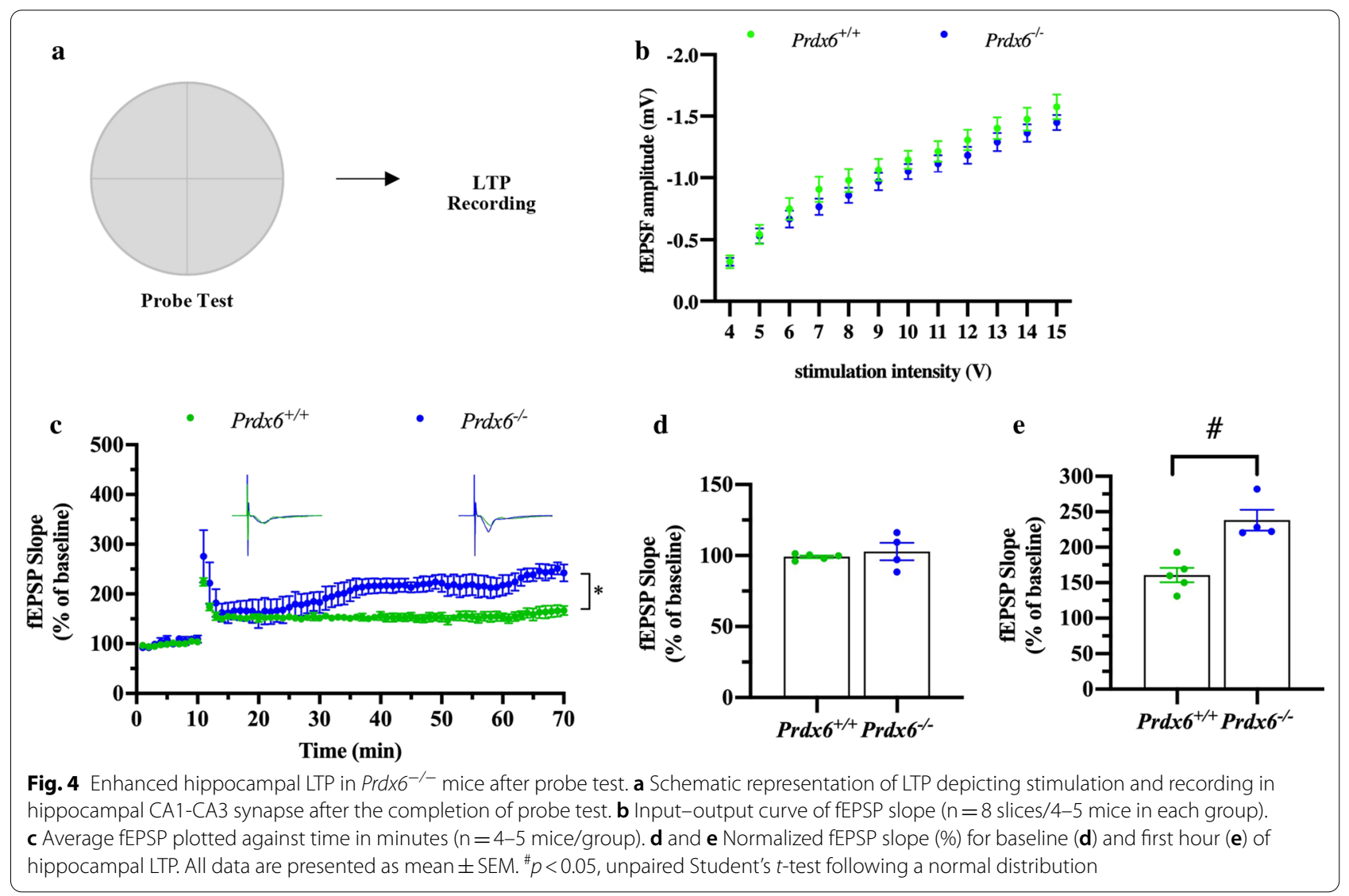




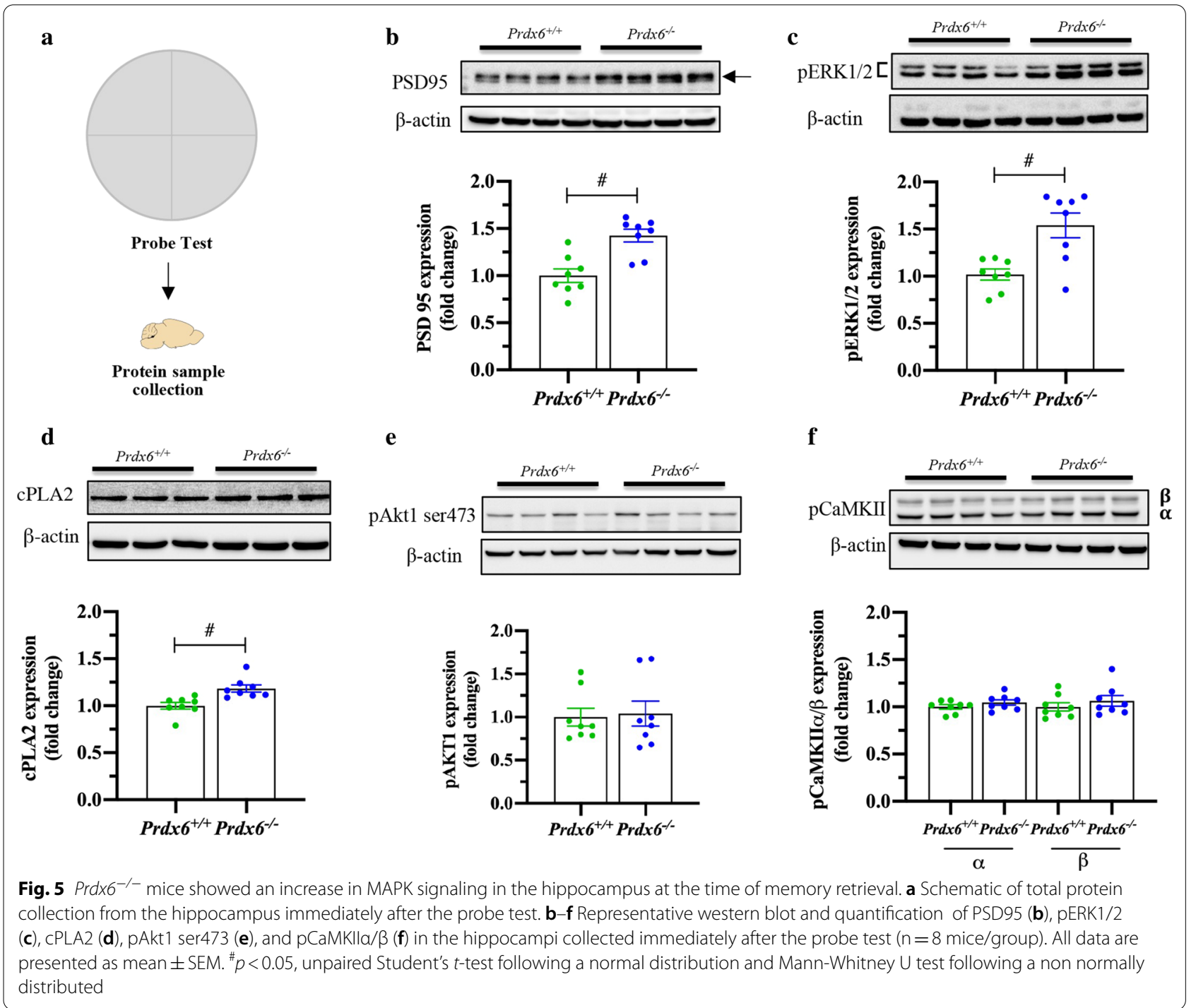

$p=0.328$, Additional file 1: Fig. S2a, c) between the two genotypes. On the other hand, we detected a significant increase in $\operatorname{PSD} 95\left(t_{14}=-4.269, p=0.001\right.$, Fig. 5b), pERK1/2 $\left(t_{14}=-3.640, p=0.003\right.$, Fig. $\left.5 \mathrm{c}\right)$, and cPLA2 $\left(t_{13}=-3.607, p=0.003\right.$, Fig. $\left.5 \mathrm{~d}\right)$ level in the hippocampus of $\operatorname{Prdx6^{-/-}}$ mice compared to $\operatorname{Prdx} 6^{+/+}$mice. Since AKT1 and CaMKII are a promising target of BDNF/TrkB signaling [36], we thus examined the levels of pAkt1 and pCaMKII. Statistical analysis revealed no significant differences of pAkt1 ( $U=29, p=0.753$, Fig. e), pCaMKII $\alpha$ $\left(t_{14}=-1.262, p=0.228\right.$, Fig. 5f $)$ and pCaMKII $\beta\left(t_{14}=-\right.$ $0.892, p=0.387$, Fig. 5f) in the hippocampi of $\operatorname{Prdx} 6^{-/-}$ mice. These results indicated that phosphorylation of ERK signaling pathway is associated with enhancement of hippocampal LTP after probe test in $\operatorname{Prdx6^{-/-}}$ mice.
Administration of MEK inhibitor, U0126, before the probe test prevents spatial memory decline of $\mathrm{Prdx}^{-/-}$mice To confirm whether excessive ERK1/2 phosphorylation is the cause of memory deficit found in $\operatorname{Prdx} 6^{-1-}$ mice, we injected MEK inhibitor (U0126) $1 \mathrm{~h}$ before the probe test (Fig. 6a) and examined mice's performance. Oneway ANOVA analysis revealed that there was no significant effect of genotype on the time for reaching the visible platform $\left(F_{(1,28)}=1.135, p=0.296\right.$, Fig. $\left.6 \mathrm{~b}\right)$, and the mean of swimming speed $\left(F_{(1,28)}=0.579, p=0.453\right.$, Fig. 6c). These results suggested that $\operatorname{Prdx6^{-1-}}$ mice have a normal sensorimotor function. In acquisition trials, using mixed-design ANOVA, there were no effects of the group as well as the interaction between the group and training day on escape latency to find a hidden platform $\left(F_{(2,28)}=1.371, p=0.270\right.$ and $F$ $(5.85,81.907)=1.394, p=0.228$, respectively, Fig. $6 \mathrm{~d})$. Both 


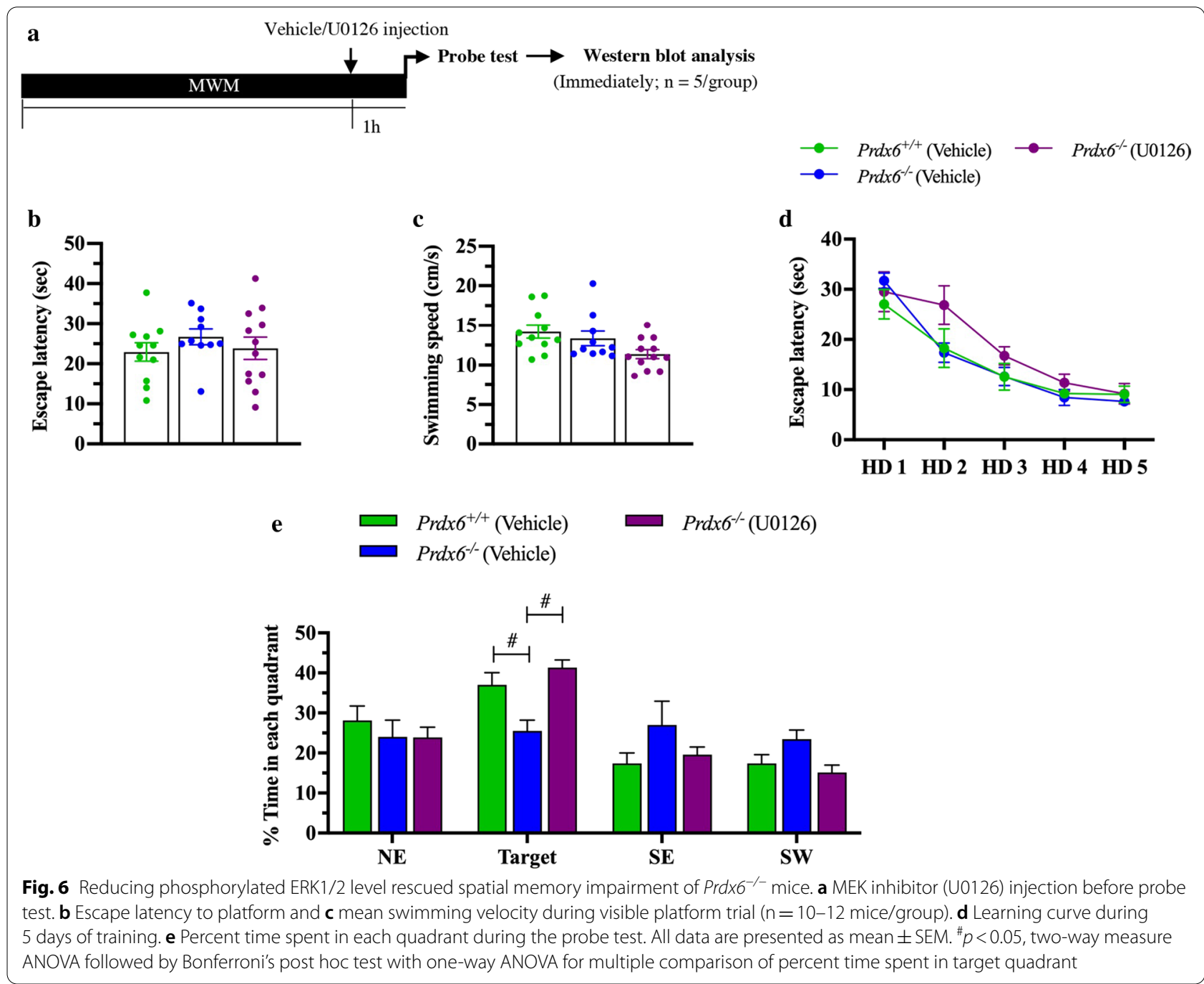

genotypes exhibited a normal ability to find the hidden platform, indicated by decreased escape latency from training day 1 to 5 as shown by the main effect of the training day $\left(F_{(2.925,81.907)}=55.537, p=0.000\right.$, Fig. $\left.6 \mathrm{~d}\right)$. In probe test, using Bonferroni-corrected $t$-test analysis with adjusted $p$ value less than 0.0167 served as a statistically significant difference, we observed that $\operatorname{Prdx} 6^{-/-}$(vehicle) spent significantly less time in the target quadrant than $\operatorname{Prdx} 6^{+/+}$(vehicle) group $\left(t_{19}=2.790, p=0.012\right.$, Fig. 6e). Interestingly, administration of U0126 significantly improved spatial memory of $\operatorname{Prdx6^{-/-}}$ mice compared with $\operatorname{Prdx} 6^{+/+}$mice without inhibitors $\left(t_{19}=-5.117, p=0.000\right.$, Fig. 6e). Besides, compared with their wild-type littermates, $\operatorname{Prdx} 6^{-/-}$ mice with U0126 administration spent comparable time in the target quadrant $\left(t_{20}=-1.354, p=0.191\right.$, Fig. 6e). We also confirmed a significant decrease in pERK1/2 $\left(F_{(2,14)}=61.776, p=0.000\right.$, Additional file 1: Fig. S3a $)$ in the hippocampi of $\operatorname{Prd} x 6^{-/-}$mice treated with $\mathrm{U} 0126$ when compared to vehicle treated knockout mice. These results proved that hyperphosphorylated ERK1/2 in the hippocampus causes spatial memory impairment in $\operatorname{Prdx6}^{-/-}$mice. Therefore, reducing ERK1/2 phosphorylation before the probe test rescues $\operatorname{Pr} d x 6^{-/-}$ mice's spatial memory deficit.

\section{Reduced reactive astrocyte marker was detected} in the hippocampi of $\mathrm{Prdx}^{-/-}$mice

PRDX6 is highly expressed in the astrocytes, which are the source of cytokine production and release [21]. Previous studies also pointed out a strong relationship between PRDX6 and activation of astrocytes [15]. Here, we proved that PRDX6 was highly expressed in the astrocytes of the hippocampi (Additional file 1: Fig. S4a). We further determined the expression of GFAP (an astrocytic 


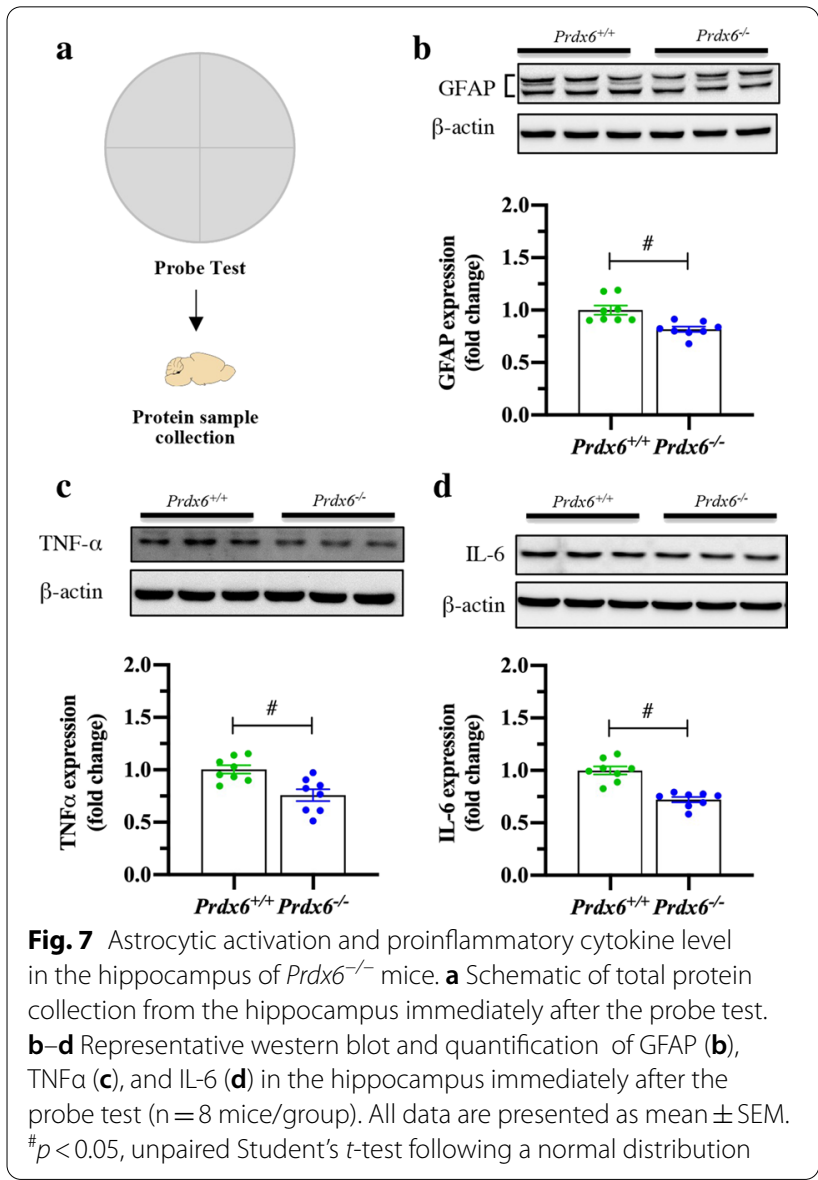

marker), TNF $\alpha$ and IL-6 in the hippocampus. We collected the protein samples immediately after the probe test (Fig. 7a). Analysis of hippocampal protein expression showed that $\operatorname{Pr} d x 6^{-1-}$ mice had significantly lower GFAP $\left(t_{14}=3.665, p=0.003\right.$, Fig. 7b), TNF $\alpha\left(t_{14}=4.565\right.$, $p=0.000$, Fig. 7c $)$ and IL-6 $\left(t_{14}=6.005, p=0.000\right.$, Fig. $\left.7 \mathrm{~d}\right)$ relative to $\operatorname{Prdx} 6^{+/+}$mice. These findings demonstrated the reduction of astrocyte activation in the hippocampus of $\operatorname{Prdx6^{-/-}}$ mice.

\section{Discussion}

In the present study, we found spatial memory impairment and homeostatic dysregulation of hippocampal long-term potentiation (LTP) in $P r d x 6^{-/-}$mice. Our results identify the novel role of PRDX6 in spatial memory formation and synaptic plasticity.

A previous report showed that PRDX6 expression is reduced in aged rats with impaired spatial memory [17]. In the present study, we found that $\operatorname{Prdx} 6^{-/-}$mice spent less time within the target quadrant in the probe test (Fig. 1f). MWM performance is affected by stressinduced anxiety-like behaviors and motor function $[35,37]$. In this study, $\operatorname{Prdx} 6^{-/-}$mice exhibited higher locomotor activity (Fig. S1), which is consistent with that shown in our recent publication [38]. Although the $\operatorname{Prdx6^{-/-}}$ mice showed higher locomotor activity in open field test, their escape latency to the visible platform (Fig. 1b) and swimming speed in MWM (Fig. 1c) are comparable to their wild-type littermates. Therefore, impaired spatial memory of the $\operatorname{Prdx6^{-/}}$ mice is attributable to loss of the $\operatorname{Prdx} 6$ gene but not to locomotor function. Our recent report showed that $\operatorname{Prdx6^{-/-}}$ mice exhibited enhanced contextual fear memory, which is also hippocampal-dependent, while their anxiety response evaluated by elevated plus-maze was normal [38]. Many pieces of evidence support that synaptic plasticity in the hippocampus reflects memory function [39, 40], and high-frequency stimulation on Schaffer collateral pathway triggers a persistent enhanced long-term potentiation (LTP) representing long-term memory formation [41]. Our results demonstrated that the spatial memory deficit was correlated with impaired LTP recorded from home-caged $\operatorname{Prd} x 6^{-/-}$mice. The aiPLA2 activity of PRDX6 is necessary for activating NADPH oxidase 2 (NOX2) by acting on its regulatory subunit in endothelial cells and macrophages [42, 43]. NOX2 is also expressed in the hippocampus [44] and affects hippocampal neuronal polarity [45]. Mice lacking regulatory subunits of NOX2 exhibited reduced LTP and impaired spatial memory in a Morris water maze [46]. We thus assume that PRDX6 and NOX2 may participate in the same or related pathway(s) for modulating synaptic plasticity and memory formation. Further investigations are required to delineate their relationship.

The ability to retrieve consolidated memory determines the memory performance during the probe test [47], which is hippocampal-dependent [48]. Reduction of hippocampal LTP is usually correlated with impaired spatial memory [49]. However, some studies report that enhanced LTP is recorded from mice demonstrating defective spatial memory [50-52], indicating LTP and memory performance can be dissociated, as is observed in $\operatorname{Prdx} 6^{-/-}$mice. Taken the impaired probe test performance together with LTP reduction of homecaged $\operatorname{Prdx} 6^{-/-}$mice, and LTP enhancement of trained $\operatorname{Prdx} 6^{-/-}$mice, loss of the Prdx6 gene can affect synaptic plasticity in the brains differently under naïve and trained conditions. Recent evidence suggests that previous neuronal activation affects the synaptic strength of a given stimulus [53]. In the hippocampus, each pyramidal cell of CA1 subregion receives many inputs, which can potentially increase synaptic plasticity [54]. Thus, the mechanisms to limit total synaptic strength are required to prevent synaptic plasticity saturation, leading to memory impairment [55]. Therefore, we assume that loss of the $\operatorname{Prd} x 6$ gene may affect homeostatic regulation of synaptic 
strength, as shown in an enhanced hippocampal LTP after a probe test.

Moreover, the hippocampal LTP recorded from trained $P r d x 6^{-1-}$ mice may be associated with accumulative levels of postsynaptic proteins and downstream signaling molecules [56]. Extracellular signal-regulated protein kinases 1 and 2 (ERK1/2) and its downstream target, cytosolic phospholipase A2 (cPLA2) are known to play crucial roles in synaptic plasticity [57-59], and memory retrieval $[60,61]$. The deficit in spatial memory performance of $\operatorname{Prdx6^{-1-}}$ mice can be rescued by suppressing ERK1/2 hyperphosphorylation with MEK inhibitor-U0126, confirming that optimal level of phosphorylated ERK1/2 is important for normal spatial memory retrieval. Our results verify that loss of PRDX6 leads to dysregulation of ERK1/2 phosphorylation, and subsequently causes impaired spatial memory recall and synaptic plasticity regulation.

Postsynaptic density protein 95 (PSD95) is crucial for synaptic plasticity and memory formation [62,63]. This synaptic protein is known to facilitate ERK1/2 activity $[64,65]$. Upregulation of PSD95 in the hippocampus of $\operatorname{Prd} \times 6^{-1-}$ mice could be the cause of excessive ERK1/2 phosphorylation during memory retrieval. PRDX6 is dominantly expressed in the astrocytes within the hippocampus [66] and regulates their functions [67]. Astrocytes are well known to play a critical role in synaptic plasticity [25], and a decrease in the reactive form of astrocytes is associated with upregulation of PSD95 $[68,69]$. Previous reports revealed that lack of PRDX6 causes downregulation of the cytokines such as TNF- $\alpha$ [15] and IL-6 [29], as well as GFAP, a reactive astrocyte marker [67]. Here, we detected downregulation of these molecules, particularly GFAP, indicating decreased reactive astrocytes in the hippocampi of $\operatorname{Prdx6^{-/-}}$ mice. Therefore, we assume that less reactive astrocytes may be correlated with dysregulation of PSD95 and ERK1/2 phosphorylation in the hippocampi, in turn, leading to enhanced LTP and defective spatial memory. Since hippocampal astrocytes play a critical role in synaptic plasticity [25], neurons may try to compensate for the lack of support from astrocytes by elevating expression levels of PSD95 and its downstream targets, pERK1/2 and cPLA2, for maintaining the homeostasis. Although these molecules are upregulated, it did not rescue $\operatorname{Prdx} 6^{-1-}$ mice's spatial memory deficit. More investigations are necessary for understanding the underlying mechanisms. Since PRDX6 plays a critical role in neurogenesis [10], the $\operatorname{Prdx6^{-1-}}$ mice may have unnoted abnormality during development. Therefore, we cannot rule out the possibility that the impaired spatial memory of $\operatorname{Prdx6^{-/-}}$ mice may be related to developmental change.
In summary, our results demonstrate the PRDX6's role in the regulation of spatial memory and synaptic plasticity through ERK1/2 signaling in the hippocampus. This study helps better understand the molecular mechanism underlying spatial memory-related disorders and suggest PRDX6 as a promising therapeutic target.

\begin{abstract}
Abbreviations
ACSF: Artificial cerebrospinal fluid; AKT: Protein kinase B; ANOVA: Analysis of variance; BDNF: Brain-derived neurotrophic factor; BSA: Bovine serum albumin; CNS: Central nervous system; CCL5: Chemokine(C-C motif)ligand 5; CAMKII:

$\mathrm{Ca}^{2+} /$ calmodulin-dependent protein kinase II; CA1: Cornu ammonis 1; CPLA2: Cytosolic phospholipase A2; ERK: Extracellular signal-regulated kinase; fEPSP: Field excitatory postsynaptic potential; GFAP: Glial fibrillary acidic protein; $\mathrm{HT}$ : Heterozygous knockout; HFS: High frequency stimulation; IL-6: Interleukin 6; IL-1 $\beta$ : Interleukin 1 $\beta$; KO: Knockout; LTP: Long-term potentiation; MEK: Mitogen activated protein kinase; MVM: Morris water maze; PRDX6: Peroxiredoxin6; PCR Polymerase chain reaction; PVDF: Polyvinylidene fluoride; PSD-95: Postsynaptic density protein 95; PTPS: Protein tyrosine phosphatase $\delta$; RIPA: Radioimmunoprecipitation assay buffer; SW: Southwest; SDS-PAGE: Sodium dodecyl sulfate polyacrylamide gel electrophoresis; TNF: Tumor necrosis factor; TBST: Tris-buffered saline; NE: Northeast; NOX2: NADPH oxidase 2.
\end{abstract}

\section{Supplementary Information}

The online version contains supplementary material available at https://doi. org/10.1186/s13041-021-00779-6.

\section{Additional file 1: $\operatorname{Pr} \times 6^{-/-}$mice showed hyperlocomotion in an open field test (Figure S1). Unchanged pro- and mature-BDNF expression in

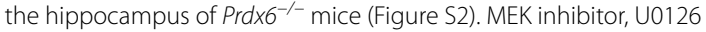 significantly decreased pERK1/2 in the hippocampus of $\operatorname{Prd} \times 6^{-1-}$ mice (Figure S3). And the expression of PRDX6 in hippocampal astrocytes after contextual testing (Figure S4). \\ Additional file 2: The list of specific primers for genotyping (Table S1) The starting point for each trial during visible platform test (Table S2). The start positions for each day during hidden platform training tri- als (Table S3). The details of antibodies and vector used in this study (Table S4). And the sample sizes of the animals for each experiment (Table S5).}

\section{Acknowledgements}

We appreciate Dr. Shun-Ping Huang for providing the $\operatorname{Prd} \times 6^{-/-}$mice. We are thankful for helpful advice from Dr. Chien-Chang Chen, Dr. Narawut Pakaprot, and Dr. Supin Chompoopong. We also appreciate for helpful experimental support from Mr. Xiao-Dong Wei. We are grateful for the support provided by the Core Facility and Teaching Research Service Center (TRSC) at Tzu Chi University.

\section{Authors' contributions}

SP; Conceptualized and performed experiments, and prepared manuscript. SJ, TP, HKC and KCL; performed experiment and prepared manuscript. IYL; Supervised the research, conceptualized experiments, and prepared manuscript. All authors read and approved the final manuscript.

\section{Funding}

This work was supported by the Ministry of Science and Technology (MOST), Taiwan (MOST-107-2410-H320-DOI-MY3), and Tzu Chi University/Tzu Chi Foundation (TCMF-SP-108-04).

\section{Availability of data and materials}

The data that support the findings of this study are available from the corresponding author upon reasonable request. 


\section{Declarations}

\section{Ethics approval and consent to participate}

All animal experiments were done in accordance with the Taiwan Ministry of Science and Technology guidelines for animals' ethical treatment. Experiments were approved by the Institutional Animal Care and Use Committee of Tzu Chi University, Taiwan (approval \#104099).

\section{Consent for publication}

Not applicable.

\section{Competing interest}

The authors report no biomedical financial interests or potential conflicts of interest.

\section{Author details demia Sinica, Taipei, Taiwan. \\ Received: 12 February 2021 Accepted: 6 April 2021 \\ Published online: 19 April 2021}

${ }^{1}$ Institute of Medical Sciences, Tzu Chi University, Hualien, Taiwan. ${ }^{2}$ Department of Physiology, Faculty of Medicine Siriraj Hospital, Mahidol University, Bangkok, Thailand. ${ }^{3}$ Department of Molecular Biology and Human Genetics, Tzu Chi University, Hualien, Taiwan. ${ }^{4}$ Institute of Biomedical Sciences, Aca-

\section{References}

1. Moffat SD. Aging and spatial navigation: what do we know and where do we go? Neuropsychol Rev. 2009;19(4):478-89.

2. Zhu H, Yan H, Tang N, Li X, Pang P, Li H, et al. Impairments of spatial memory in an Alzheimer's disease model via degeneration of hippocampal cholinergic synapses. Nat Commun. 2017;8(1):1676.

3. Gould NF, Holmes MK, Fantie BD, Luckenbaugh DA, Pine DS, Gould TD, et al. Performance on a virtual reality spatial memory navigation task in depressed patients. Am J Psychiatry. 2007;164(3):516-9.

4. Baierle M, Nascimento SN, Moro AM, Brucker N, Freitas F, Gauer B, et al. Relationship between inflammation and oxidative stress and cognitive decline in the institutionalized elderly. Oxid Med Cell Longev. 2015;2015:804198.

5. Kamsler A, Segal M. Hydrogen peroxide modulation of synaptic plasticity. J Neurosci. 2003;23(1):269-76.

6. Davis SM, Pennypacker KR. Targeting antioxidant enzyme expression as a therapeutic strategy for ischemic stroke. Neurochem Int. 2017;107:23-32.

7. Lee $\mathrm{KH}$, Cha M, Lee BH. Neuroprotective effect of antioxidants in the brain. Int J Mol Sci. 2020;21(19):7152.

8. Fisher AB. Peroxiredoxin 6: a bifunctional enzyme with glutathione peroxidase and phospholipase A2 activities. Antioxid Redox Signal. 2011;15(3):831-44.

9. Tulsawani R, Kelly LS, Fatma N, Chhunchha B, Kubo E, Kumar A, Singh DP. Neuroprotective effect of peroxiredoxin 6 against hypoxia-induced retinal ganglion cell damage. BMC Neurosci. 2010;11:125

10. Yeo IJ, Park MH, Son DJ, Kim JY, Nam KT, Hyun BK, et al. PRDX6 inhibits neurogenesis through downregulation of WDFY1-mediated TLR4 signal. Mol Neurobiol. 2019;56(5):3132-44.

11. Manevich Y, Fisher AB. Peroxiredoxin 6, a 1-Cys peroxiredoxin, functions in antioxidant defense and lung phospholipid metabolism. Free Radic Biol Med. 2005;38(11):1422-32.

12. Li H, Benipal B, Zhou S, Dodia C, Chatterjee S, Tao JQ, et al. Critical role of peroxiredoxin 6 in the repair of peroxidized cell membranes following oxidative stress. Free Radic Biol Med. 2015;87:356-65.

13. Fatma N, Kubo E, Takamura Y, Ishihara K, Garcia C, Beebe DC, et al. Loss of NF-kappaB control and repression of $\operatorname{Prd} \times 6$ gene transcription by reactive oxygen species-driven SMAD3-mediated transforming growth factor beta signaling. J Biol Chem. 2009;284(34):22758-72.

14. Yun HM, Jin P, Han JY, Lee MS, Han SB, Oh KW, et al. Acceleration of the development of Alzheimer's disease in amyloid beta-infused peroxiredoxin 6 overexpression transgenic mice. Mol Neurobiol. 2013:48(3):941-51.
15. Yun HM, Choi DY, Oh KW, Hong JT. PRDX6 exacerbates dopaminergic neurodegeneration in a MPTP mouse model of Parkinson's disease. Mol Neurobiol. 2015;52(1):422-31.

16. Sundar IK, Chung S, Hwang JW, Arunachalam G, Cook S, Yao H, et al. Peroxiredoxin 6 differentially regulates acute and chronic cigarette smoke mediated lung inflammatory response and injury. Exp Lung Res. 2010;36(8):451-62.

17. Lubec J, Smidak R, Malikovic J, Feyissa DD, Korz V, Hoger H, et al. Dentate gyrus peroxiredoxin 6 levels discriminate aged unimpaired from impaired rats in a spatial memory task. Front Aging Neurosci. 2019;11:198.

18. Tu Q, Xiong Y, Fan L, Qiao B, Xia Z, Hu L, et al. Peroxiredoxin 6 attenuates ischemia and hypoxiainduced liver damage of braindead donors. Mol Med Rep. 2016;13(1):753-61.

19. Jia G, Tan B, Ma J, Zhang L, Jin X, Li C. Prdx6 upregulation by curcumin attenuates ischemic oxidative damage via SP1 in rats after stroke. Biomed Res Int. 2017:2017:6597401.

20. Vazquez-Medina JP, Tao JQ, Patel P, Bannitz-Fernandes R, Dodia C, Sorokina EM, et al. Genetic inactivation of the phospholipase A2 activity of peroxiredoxin 6 in mice protects against LPS-induced acute lung injury. Am J Physiol Lung Cell Mol Physiol. 2019;316(4):L656-68.

21. Buonora JE, Mousseau M, Jacobowitz DM, Lazarus RC, Yarnell AM, Olsen $\mathrm{CH}$, et al. Autoimmune profiling reveals peroxiredoxin 6 as a candidate traumatic brain injury biomarker. J Neurotrauma. 2015;32(22):1805-14.

22. Yun HM, Park KR, Kim EC, Hong JT. PRDX6 controls multiple sclerosis by suppressing inflammation and blood brain barrier disruption. Oncotarget. 2015;6(25):20875.

23. Choi SS, Lee HJ, Lim I, Satoh J, Kim SU. Human astrocytes: secretome profiles of cytokines and chemokines. PLoS ONE. 2014;9(4):e92325.

24. Van Wagoner NJ, Oh JW, Repovic P, Benveniste EN. Interleukin-6 (IL-6) Production by astrocytes: autocrine regulation by IL- 6 and the soluble IL-6 receptor. J Neurosci. 1999:19(13):5236-44.

25. Ota Y, Zanetti AT, Hallock RM. The role of astrocytes in the regulation of synaptic plasticity and memory formation. Neural Plast. 2013;2013:185463.

26. Zhou Y, Shao A, Yao Y, Tu S, Deng Y, Zhang J. Dual roles of astrocytes in plasticity and reconstruction after traumatic brain injury. Cell Commun Signal. 2020;18(1):62.

27. Yun HM, Park KR, Lee HP, Lee DH, Jo M, Shin DH, et al. PRDX6 promotes lung tumor progression via its GPX and PLA2 activities. Free Radic Biol Med. 2014;69:367-76.

28. Pacifici F, Arriga R, Sorice GP, Capuani B, Scioli MG, Pastore D, et al. Peroxiredoxin 6 , a novel player in the pathogenesis of diabetes. Diabetes. 2014;63(10):3210-20.

29. Melhem H, Spalinger MR, Cosin-Roger J, Atrott K, Lang S, Wojtal KA, et al. Prdx6 deficiency ameliorates DSS colitis: relevance of compensatory antioxidant mechanisms. J Crohns Colitis. 2017;11(7):871-84.

30. Kim SY, Chun E, Lee KY. Phospholipase A(2) of peroxiredoxin 6 has a critical role in tumor necrosis factor-induced apoptosis. Cell Death Differ. 2011;18(10):1573-83.

31. Wang X, Phelan SA, Forsman-Semb K, Taylor EF, Petros C, Brown A, et al. Mice with targeted mutation of peroxiredoxin 6 develop normally but are susceptible to oxidative stress. J Biol Chem. 2003;278(27):25179-90.

32. Zhang W, Liu X, Xu W, Wei X, Zhang J, Wang B. Effects of BDNF-ERK-CREB signaling pathways on cognitive function and neural plasticity in a rat model of depression. Int J Clin Exp Med. 2019;12(6):6684-94.

33. Vorhees CV, Williams MT. Morris water maze: procedures for assessing spatial and related forms of learning and memory. Nat Protoc 2006; 1 (2):848-58

34. Huang IY, Hsu YL, Chen CC, Chen MF, Wen ZH, Huang HT, et al. Excavatolide-B enhances contextual memory retrieval via repressing the delayed rectifier potassium current in the hippocampus. Mar Drugs. 2018;16(11):405.

35. Higaki A, Mogi M, Iwanami J, Min LJ, Bai HY, Shan BS, et al. Recognition of early stage thigmotaxis in Morris water maze test with convolutional neural network. PLoS ONE. 2018;13(5):e0197003.

36. Wang R, Holsinger RMD. Exercise-induced brain-derived neurotrophic factor expression: therapeutic implications for Alzheimer's dementia. Ageing Res Rev. 2018;48:109-21.

37. Pritchett D, Taylor AM, Barkus C, Engle SJ, Brandon NJ, Sharp T, et al. Searching for cognitive enhancement in the Morris water maze: better 
and worse performance in D-amino acid oxidase knockout (Dao(-/-)) mice. Eur J Neurosci. 2016;43(7):979-89.

38. Phasuk S, Pairojana T, Suresh P, Yang $\mathrm{CH}$, Roytrakul S, Huang SP, et al. Enhanced contextual fear memory in peroxiredoxin 6 knockout mice is associated with hyperactivation of MAPK signaling pathway. Mol Brain. 2021;14(1):42

39. Van Hulzen ZJ, Van der Staay FJ. Spatial memory processing during hippocampal long-term potentiation in rats. Physiol Behav. 1991;50(1):121-7.

40. Bliss TV, Collingridge GL. A synaptic model of memory: long-term potentiation in the hippocampus. Nature. 1993;361(6407):31-9.

41. Glasgow SD, Wong EW, Thompson-Steckel G, Marcal N, Seguela P, Ruthazer ES, et al. Pre- and post-synaptic roles for DCC in memory consolidation in the adult mouse hippocampus. Mol Brain. 2020;13(1):56.

42. Vazquez-Medina JP, Dodia C, Weng L, Mesaros C, Blair IA, Feinstein $\mathrm{SI}$, et al. The phospholipase A2 activity of peroxiredoxin 6 modulates NADPH oxidase 2 activation via lysophosphatidic acid receptor signaling in the pulmonary endothelium and alveolar macrophages. FASEB J. 2016;30(8):2885-98.

43. Ambruso DR. Peroxiredoxin-6 and NADPH oxidase activity. Methods Enzymol. 2013:527:145-67.

44. Qiu LL, Luo D, Zhang H, Shi YS, Li YJ, Wu D, et al. Nox-2-mediated phenotype loss of hippocampal parvalbumin interneurons might contribute to postoperative cognitive decline in aging mice. Front Aging Neurosci. 2016:8:234.

45. Wilson C, Nunez MT, Gonzalez-Billault C. Contribution of NADPH oxidase to the establishment of hippocampal neuronal polarity in culture. J Cell Sci. 2015:128(16):2989-95

46. Kishida KT, Hoeffer CA, Hu D, Pao M, Holland SM, Klann E. Synaptic plasticity deficits and mild memory impairments in mouse models of chronic granulomatous disease. Mol Cell Biol. 2006;26(15):5908-20.

47. Moridi H, Sarihi A, Habibitabar E, Shateri H, Salehi I, Komaki A, et al. Effects of post-training administration of $L Y 341495$, as an $\mathrm{mGluR2/3}$ antagonist on spatial memory deficit in rats fed with high-fat diet. IBRO Rep. 2020;9:241-6.

48. Harand C, Bertran F, La Joie R, Landeau B, Mezenge F, Desgranges B, et al. The hippocampus remains activated over the long term for the retrieval of truly episodic memories. PLOS ONE. 2012;7(8):e43495.

49. Li XL, Aou S, Oomura Y, Hori N, Fukunaga K, Hori T. Impairment of long-term potentiation and spatial memory in leptin receptor-deficient rodents. Neuroscience. 2002;113(3):607-15.

50. Meiri N, Sun MK, Segal Z, Alkon DL. Memory and long-term potentiation (LTP) dissociated: normal spatial memory despite CA1 LTP elimination with Kv1.4 antisense. Proc Natl Acad Sci USA 1998;95(25):15037-42.

51. Uetani N, Kato K, Ogura H, Mizuno K, Kawano K, Mikoshiba K, et al. Impaired learning with enhanced hippocampal long-term potentiation in PTPdelta-deficient mice. EMBO J. 2000;19(12):2775-85.

52. Garcia-Alvarez G, Shetty MS, Lu B, Yap KA, Oh-Hora M, Sajikumar S, et al, Impaired spatial memory and enhanced long-term potentiation in mice with forebrain-specific ablation of the Stim genes. Front Behav Neurosci. 2015;9:180.

53. Abraham WC, Bear MF. Metaplasticity: the plasticity of synaptic plasticity. Trends Neurosci. 1996;19(4):126-30.

54. Debanne D, Gahwiler BH, Thompson SM. Heterogeneity of synaptic plasticity at unitary CA3-CA1 and CA3-CA3 connections in rat hippocampal slice cultures. J Neurosci. 1999;19(24):10664-71.
55. Nguyen-Vu TB, Zhao GQ, Lahiri S, Kimpo RR, Lee H, Ganguli S, et al. A saturation hypothesis to explain both enhanced and impaired learning with enhanced plasticity. Elife. 2017. https://doi.org/10.7554/eLife.20147.

56. Pineda VV, Athos JI, Wang H, Celver J, Ippolito D, Boulay G, et al. Removal of Gia1 constraints on adenylyl cyclase in the hippocampus enhances LTP and impairs memory formation. Neuron. 2004;41(1):153-63.

57. Thomas GM, Huganir RL. MAPK cascade signalling and synaptic plasticity. Nat Rev Neurosci. 2004;5(3):173-83.

58. Toyoda H, Zhao MG, Xu H, Wu L, Ren M, Zhuo M. Requirement of extracellular signal-regulated kinase/mitogen-activated protein kinase for long-term potentiation in adult mouse anterior cingulate cortex. Mol Pain. 2007:3:36.

59. Gaudreault SB, Chabot C, Gratton JP, Poirier J. The caveolin scaffolding domain modifies 2-amino-3-hydroxy-5-methyl-4-isoxazole propionate receptor binding properties by inhibiting phospholipase A2 activity. J Biol Chem. 2004;279(1):356-62.

60. Besnard A, Caboche J, Laroche S. Recall and reconsolidation of contextual fear memory: differential control by ERK and Zif268 expression dosage. PLOS ONE. 2013;8(8):e72006.

61. Schaeffer EL, Gattaz WF. Requirement of hippocampal phospholipase A2 activity for long-term memory retrieval in rats. J Neural Transm (Vienna). 2007;1 14(3):379-85

62. Béïque JC, Andrade R. PSD-95 regulates synaptic transmission and plasticity in rat cerebral cortex. J Physiol. 2003;546(Pt 3):859-67.

63. Delint-Ramirez I, Salcedo-Tello P, Bermudez-Rattoni F. Spatial memory formation induces recruitment of NMDA receptor and PSD-95 to synaptic lipid rafts. J Neurochem. 2008:106(4):1658-68.

64. Xie F, Padival M, Siegel RE. Association of PSD-95 with ErbB4 facilitates neuregulin signaling in cerebellar granule neurons in culture. J Neurochem. 2007;100(1):62-72.

65. Kennedy MB. Synaptic signaling in learning and memory. Cold Spring Harb Perspect Biol. 2013;8(2):a016824.

66. Asuni AA, Gray B, Bailey J, Skipp P, Perry VH, O'Connor V. Analysis of the hippocampal proteome in ME7 prion disease reveals a predominant astrocytic signature and highlights the brain-restricted production of clusterin in chronic neurodegeneration. J Biol Chem. 2014;289(7):4532-45.

67. Pankiewicz JE, Diaz JR, Marta-Ariza M, Lizinczyk AM, Franco LA, Sadowski MJ. Peroxiredoxin 6 mediates protective function of astrocytes in Abeta proteostasis. Mol Neurodegener. 2020;15(1):50.

68. Willard SL, Hemby SE, Register TC, McIntosh S, Shively CA. Altered expression of glial and synaptic markers in the anterior hippocampus of behaviorally depressed female monkeys. Neurosci Lett. 2014;563:1-5.

69. Lechuga-Sancho AM, Arroba Al, Frago LM, Garcia-Caceres C, de Celix $A D$, Argente J, et al. Reduction in the number of astrocytes and their projections is associated with increased synaptic protein density in the hypothalamus of poorly controlled diabetic rats. Endocrinology. 2006;147(11):5314-24.

\section{Publisher's Note}

Springer Nature remains neutral with regard to jurisdictional claims in published maps and institutional affiliations.

Ready to submit your research? Choose BMC and benefit from:

- fast, convenient online submission

- thorough peer review by experienced researchers in your field

- rapid publication on acceptance

- support for research data, including large and complex data types

- gold Open Access which fosters wider collaboration and increased citations

- maximum visibility for your research: over 100M website views per year

At $\mathrm{BMC}$, research is always in progress.

Learn more biomedcentral.com/submissions 